\title{
Mit tanulhatunk az európai megújuló tenderekböl? Néhány európai példa elemzése és a követendő tapasztalatok a METÁR-tenderek esetleges továbbfejlesztéséhez
} What Can We Learn from European Renewable Tendering Schemes? Analysis of Selected European Examples and Lessons to Learn for Further Development of the Hungarian Renewable Tenders

\section{Tóth Tamás és Somossy Éva Szabina https://doi.org/10.47707/Kulugyi_Szemle.2020.3.06}

\begin{abstract}
Összefoglaló: Az utóbbi időszakban megfigyelhető, hogy a támogatási költségek csökkentése érdekében, valamint az uniós követelményeknek megfelelően egyre több tagállam pályázati úton, tender formájában ítéli oda a működési támogatásokat (prémiumokat). Ennek megfelelően a huszonhét uniós tagállam és a kilépő Egyesült Királyság közül már húsz alkalmaz ilyen típusú tenderrendszereket. A jelen tanulmány célja, hogy hat kiemelt ország (Dánia, az Egyesült Királyság, Görögország, Hollandia, Lengyelország és Németország) esetében részletesebben is megvizsgálja a megújuló tenderrendszerek múködését, valamint értékelje azok eredményeit. A hazai megújuló támogatási rendszer (METÁR) rövid ismertetése és az első eredmények értékelése után arra keressük a választ, hogy a bemutatott európai példák milyen tanulságokkal szolgálhatnak a hazai tenderek esetleges továbbfejlesztése során.
\end{abstract}

Kulcsszavak: megújuló tenderrendszerek, megújuló támogatási rendszer (METÁR), Dánia, Egyesült Királyság, Görögország, Hollandia, Lengyelország, Németország

\begin{abstract}
In recent years, a trend towards competitive bidding processes (tenders) can be observed in EU Member States in line with EU obligations on cost effective and market-oriented (premium) support for renewable electricity. At present, twenty out of the twenty-seven EU Member States and the United Kingdom use some kind of renewable energy sources (RES) tendering schemes. The aim of this report is to analyse the tender design elements and the outcome of the RES tendering schemes of Denmark, Germany, the Netherlands, the United Kingdom, Greece and Poland. After a brief description of the Hungarian "METÁR" renewable tendering scheme and the presentation of the first results, we tried to find best practice examples to follow in case of further development of the Hungarian RES tenders.
\end{abstract}

Keywords: renewable energy sources (RES) tendering schemes, renewable tendering scheme "METÁR", Denmark, United Kingdom, Greece, the Netherlands, Poland, Germany

\section{Bevezető}

A megújuló energiaforrásokon alapuló (a továbbiakban: megújuló) energiatermelés támogatásának odaítélésére kialakított tenderek piaci alapú, versenyeztetéses eljárások, amelyek során általában egy bizonyos villamosenergia-kapacitás (megawatt, MW) 


\section{Külügyi Szemle}

beépítésére, vagy bizonyos, előre meghatározott nagyságú villamosenergia-mennyiség (megawattóra, MWh) megtermelésére vonatkozóan lehet pályázatot benyújtani. A pályázók általában vagy a támogatott árra (piaci ár + prémium), vagy magára a támogatás nagyságára (prémium) vonatkozóan tesznek ajánlatot, és zömében a legalacsonyabb támogatást igénylő projektek nyerik meg a tendert.

A tender lehet technológiaspecifikus (csak egy bizonyos megújuló technológiára vonatkozó, pl. fotovoltaikus (PV) naperőmúvek, szárazföldi szélerőmúvek, biomaszsza-erőmúvek), illetve technológiasemleges is. A górcső alá vett országok többsége támogatási formaként lebegố prémiumot alkalmaz, azaz a támogatás nagysága a tenderen elnyert támogatott ár és az aktuális piaci átlagár különbsége (kivéve Dánia, ahol fix prémiumot vezettek be 2018-ban). Általában az ajánlati ár nagysága dönti el, hogy ki nyeri el a támogatást, amelynek időtartama jellemzően 15-20 év.

A megújuló tenderrendszereket (aukciós mechanizmusokat), illetve azok kialakítási lehetőségeit számos külföldi tanulmány vizsgálta már (például: Matthäus, 2020; Haufe és Ehrhart, 2018; EBRD, 2018; Mora, Kitzing, Rosenlund Soysal, Steinhilber, Del Río, Wigand, Klessmann, Tiedermann, Amazo, Welisch, Kreiß, Fitch Roy és Woodman, 2017; IRENA, 2015). A megújuló tenderrendszerekre vonatkozóan hazánkban készült publikus elemzésről nincs tudomásunk.

Az Európai Unió 28 tagállamából² jelenleg húszban alkalmaznak valamilyen formában tendereket a megújuló alapú villamosenergia-termelési támogatások odaítéléséhez: Belgium, Dánia, az Egyesült Királyság, Észtország, Finnország, Franciaország, Görögország, Hollandia, Horvátország, Lengyelország, Litvánia, Luxemburg, Magyarország, Málta, Németország, Olaszország, Portugália, Spanyolország, Szlovákia és Szlovénia.

Az egyes tenderrendszerek múködését, illetve azok tapasztalatait világszinten az IRENA (2019), európai vonatkozásban pedig a CEER (2018) és az AURES II (2020) projekt keretében vizsgálták/vizsgálják részletesen.

Mivel a jelenleg is zajló AURES II projekt keretében az európai országok közül eddig csupán Dánia, az Egyesült Királyság, Görögország, Hollandia, Lengyelország és Németország megújuló tenderrendszereit elemezték ki, tanulmányunk e hat állam tendereztetési gyakorlatát kívánja röviden bemutatni, illetve a hazai METÁR-tender értékelése után a rendszer továbbfejlesztése szempontjából hasznos, követendő külföldi példákat foglalja össze.

1 Természetesen az ajánlati áron kívül egyéb szempontokat is figyelembe lehet venni, pl. munkahelyteremtési hatás, fenntarthatóság, hálózati szúkületek stb.

2 Megjegyzés: az Egyesült Királyság 2020. február 1-jén kilépett az EU-ból, de december 31-ig még tart az átmeneti időszak, ezért gyakorlatilag még az EU tagjának lehet tekinteni. 


\section{Néhány kiemelt európai ország tenderrendszereinek részletes elemzése az AURES II projekt eredményei alapján}

\section{Németország ${ }^{3}$}

A megújuló energiaforrásokról szóló (Erneuerbare-Energien-Gesetz, EEG) 2017-es német törvény (Buzer.de, 2020) megújuló technológiánkénti bontásban határozott meg éves maximális beépítendő kapacitásmennyiségeket. Az elérésükhöz alapvetően technológiaspecifikus tendereket írnak ki, minimális technológiánkénti kapacitáskorláttal. Ezenfelül technológiasemleges tendereken is lehet pályázni: egy évben kétszer a fotovoltaikus naperőművek és a szárazföldi szélerőművek terén; 2019 és 2021 között évente egyszer ún. innovációs tendereket ${ }^{4}$ is meghirdetnének, amelyeken minden megújuló projekt pályázhatna (utóbbira eddig még nem került sor).

Nemzetközi tenderek meghirdetésére is lehetőség van a fotovoltaikus naperőművek és a szárazföldi szélerőművek esetében. (Ilyen, kölcsönösen nyitott nemzetközi pilot tendert eddig Németország és Dánia rendezett 2016-ban, a földre szerelt fotovoltaikus naperőművekre vonatkozóan.)

A német tendereken az adott megújuló projekt kapacitására (pl. kilowatt, kW), valamint a támogatott árra (a mindenkori piaci ár + lebegő prémium) tett ajánlattal lehet indulni. A tenderek egykörösek, zárt borítékolásúak (sealed bid). Az elnyerhető támogatás időtartama 20 év. Az odaítélésekor csak a pályázati ár dönt, azaz a legolcsóbb ajánlatok nyernek el támogatást - mindaddig, amíg a tenderen meghirdetett kapacitásmenynyiség ki nem merül (támogatási plafont nem határoznak meg). Megjegyzendő, hogy a szárazföldi szélerőművekre vonatkozó tenderek esetében az ajánlati árakat egy ún. referencia-szélerőmúhöz (100\%) képest korrigálják (bonus-malus rendszer alapján), és ily módon rangsorolják a projekteket (Buzer.de, 2020). E módszer célja a hálózati szúk keresztmetszetek kezelése (a szélenergia tekintetében rosszabb adottságú telephelyeket felül-, a jobbakat alulkompenzálja).

A német tenderek alapvetően ajánlati árasak (pay-as-bid), azaz a nyertes projektek az általuk felajánlott támogatott árat fogják kapni.

A tendereken való részvétel előfeltétele az ajánlati biztosíték (bid bond), amit bankgarancia formájában lehet teljesíteni. PV-tenderek esetén a szerződéskötés utáni 10 napon belül teljesítési biztosíték (completion bond) elhelyezése is szükséges. A tenderen támogatást el nem nyerő pályázók az ajánlati biztosítékot visszakapják, míg a teljesítési biztosíték hiánya egy nyertes projekt esetén a támogatási jogosultság és az ajánlati biztosíték

3 Sach, Lotz és Blücher, 2019 alapján.

4 Ezen innovációs tenderek célja, hogy új típusú árazási és aukciós technikákat próbáljanak ki. A tervek szerint lebegő prémium helyett fix prémiumot kapnának a nyertes megújuló projektek, ily módon a befektetőknek kisebb piaci kockázatot kell viselniük. Negatív piaci árak esetén a nyertes projektek már nem kapnának támogatást. 
elvesztését vonja maga után. A nyertes PV-projekteket a szerződéskötést követő 18 hónapon belül lehet szankció nélkül megvalósítani, utána a támogatott árat fokozatosan csökkentik. Amennyiben 24 hónap után sem készül el a projekt, a nyertes pályázó elveszíti a támogatási jogosultságot, valamint kW-onként 25 eurós büntetést kell fizetnie.

A biomassza-erőmúvek külön aukción szerezhetnek támogatási jogosultságot, azzal az eltéréssel, hogy ott már meglévő létesítmények is pályázhatnak - a kötelező átvételi támogatási jogosultság lejárta után, legfeljebb további 10 évre. A tengeri szélerőmúvi projektekre vonatkozóan szintén külön tendereket hirdetnek meg.

Az eddigi gyakorlat szerint a németek inkább többször, de kevesebb beépített kapacitásra vonatkozó tendereket írnak ki, ami a pályázók számára nagyobb kiszámíthatóságot, illetve a megújuló kapacitás folyamatos bővülését eredményezi.

Az AURES II (2020) projekt keretében megvizsgálták a német tenderek eredményességét és költséghatékonyságát is. Az eredményesség függ egyrészt attól, hogy a hatékony versenyhez elegendő számú pályázat érkezik-e be (verseny mértéke [\%] = pályázókapacitás/kiírt kapacitás), másrészt, hogy milyen a tenderen támogatást elnyerő projektek megvalósítási aránya. A költséghatékonyság (más néven statikus hatékonyság) vizsgálata során azt nézik, hogy egy előre meghatározott célérték a lehető legalacsonyabb összköltséggel valósítható-e meg. A tenderek esetében ehhez megfelelő mértékú verseny szükséges. Általánosságban ez akkor valósul meg, ha a beérkezett ajánlatok nagysága meghaladja a kiírt kapacitás mennyiségét. Emellett érdemes megvizsgálni a nyertes pályázatok ajánlati átlagárának a maximált árhoz viszonyított mértékét, illetve a tender előtti támogatott árakhoz való viszonyát.

Az alábbiakban csak a PV-tenderek eredményességét és költséghatékonyságát kívánjuk értékelni. Az eredményesség tekintetében annak egyik szempontja egyértelmúen teljesült. A PV-tenderek minden egyes fordulójában - az időszak egészére nézve háromszoros - túljelentkezés mutatkozott.

A másik szempont a nyertes projektek megvalósítási aránya. A PV-projektek esetében a 2015-2017 között kiírt tendereken támogatást nyert kapacitások már szinte 90-100 százalékban megépültek. A pályázók kérdőives felmérése alapján a megvalósítási ráta egyfelől a hatékony szankcionálási rendszernek, illetve előminősítési kritériumoknak, valamint a támogatási jogosultság átruházási lehetőségének köszönhető, míg másfelól a pályázók a telephely-módosítás fontos szerepét emelték ki a beruházás megvalósításában.

A PV-tenderek bevezetése óta jelentősen, nagyjából a felére csökkent a nyertes pályázók átlagos ajánlati ára (1. ábra). Az árcsökkenés nem egy új fejlemény a német támogatási rendszerben, hiszen már a tenderrendszer bevezetése előtt is megfigyelhető volt a támogatott árak degressziója. Ha úgy vesszük, a 2015 óta tartó árcsökkenés a korábbi trend folytatását jelenti, de ez a megnövekedett verseny eredménye. Kijelenthető tehát, hogy a német PV-tenderek mindeddig költséghatékonyak voltak. 


\section{1. ábra ${ }^{5}$}

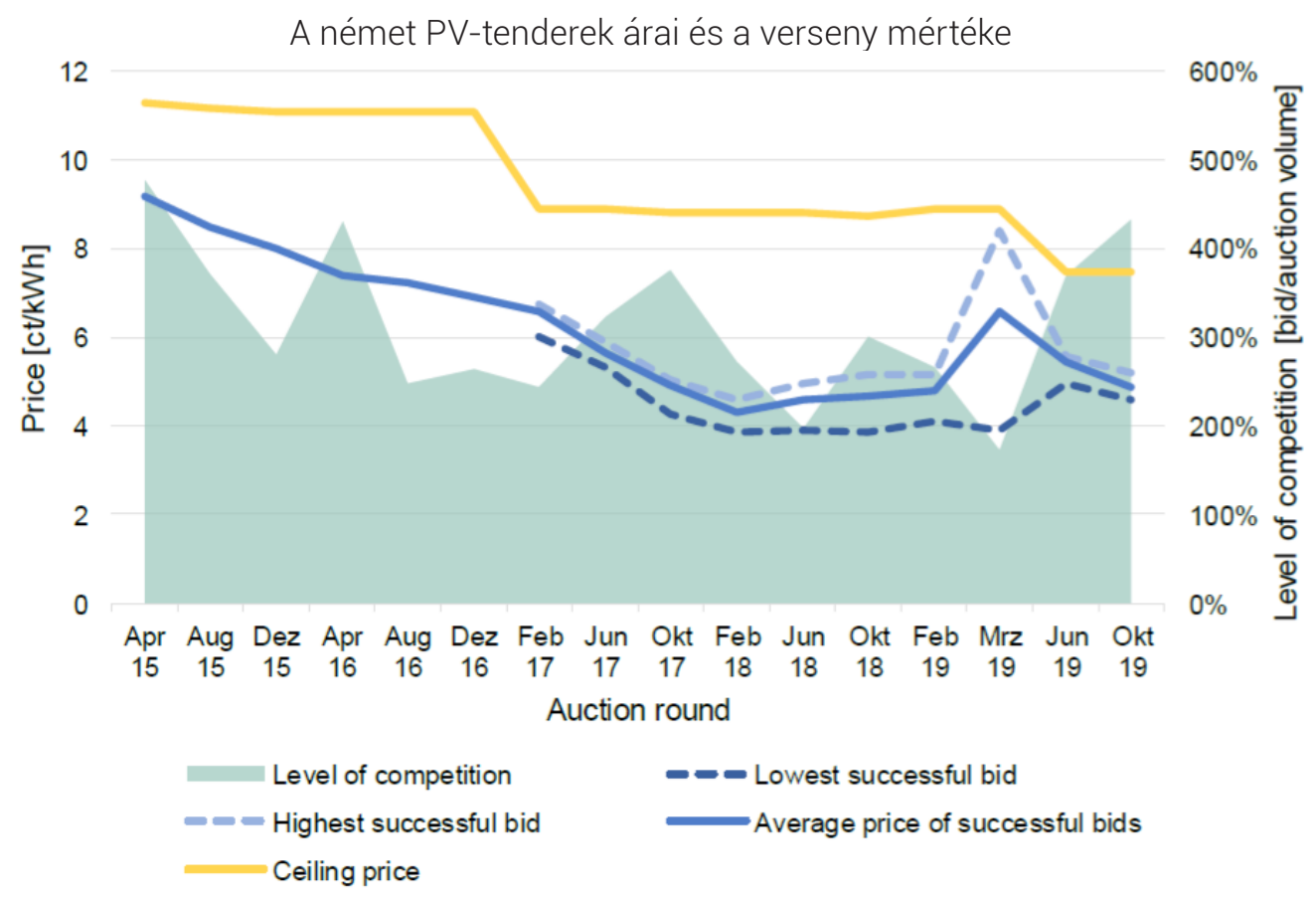

Egyesült Királyság6

A britek korábban is tender - 1990 és 1998 között az ún. Non-Fossil Fuel Obligation - keretében ítélték oda a támogatásokat a nem fosszilis erőmúvek építéséhez és fejlesztéséhez, tehát e téren már van tapasztalatuk. Igaz, hogy 2002-től zöld bizonyítvány támogatta a megújuló erőmúvek múködését, de azt az új erőmúvek 2017 óta már nem igényelhetik. Helyette újra tenderrendszert vezettek be (Contract for Difference Scheme, CfD) mind a megújuló, mind a nukleáris erőmúvekre vonatkozóan, és az első fordulót már 2015-ben meg is rendezték.

A brit CfD-tenderek zárt borítékolású, egyenáras, technológiaspecifikus aukciók, amelyeken a nyertesek 15 évre kapnak támogatást. A brit kormány határozza meg a technológiaspecifikus maximált árakat, oly módon, hogy azok a korábbi zöld bizonyítványhoz hasonló megtérülést biztosítsanak a befektetők számára. A pályázók legfeljebb ilyen árral adhatnak be pályázatot, és a legolcsóbb ajánlatok nyernek. Összesen három olyan költségvetési "kosarat” hoztak létre, ${ }^{7}$ amelyekre vonatkozóan tendereket lehet meghirdetni:

5 Forrás: Sach, Lotz és Blücher, 2019, 32. 0.

6 Woodman és Fitch-Roy, 2019 alapján.

7 A tervek szerint azonban a jövőben technológiasemleges tendereztetésre kívánnak áttérni. 


\section{Külügyi Szemle}

- érettebb technológiákkal lehet indulni (pl. PV, szárazföldi szélerőmúvek);

- éretlenebb technológiákra adhatnak be pályázatot (pl. tengeri szélerőmúvek);

- biomasszatechnológiák pályázhatnak (még nem hirdették meg).

A támogatást a tenderen meghatározott kiinduló ár és a referencia piaci ár alapján számolják ki. Amennyiben az utóbbi meghaladja a kiinduló árat, a termelő fizeti ki a különbséget (vö. németek, ahol nincs ilyen szabály).

Az illetékes államtitkár éves költségvetési minimum-, illetve maximumkorlátokat (MW vagy font) határozhat meg bizonyos megújuló technológiák vagy technológiacsoportok vonatkozásában.

Egy pályázó egyszerre legfeljebb tízféle pályázatot nyújthat be: különböző kapacitásra, ajánlati árra, illetve kereskedelmi üzembe lépési időpontra vonatkozóan. A legolcsóbb ajánlatok kerülnek a preferencialista élére, ám amennyiben a költségvetési korlát miatt nem kerülne be a támogatottak közé egy adott projekt, akkor az adott pályázó drágább, de kisebb kapacitást felajánló pályázatát fogadják el. Ily módon próbálják megoldani, hogy egyetlen pályázó se essen ki csupán a költségvetési korlát miatt. Sajnos, az egyes ajánlatok nem publikusak, ezért a pályázók stratégiája nem követhető nyomon.

Mindeddig három ilyen jellegú CfD-aukciót tartottak: 2015-ben, 2017-ben, illetve 2019-ben. Érdekes módon, az érettebb technológiák (pl. PV, illetve szárazföldi szélerőmúvek) számára csak az elsőn hirdettek meg aukciót.

Ha az ajánlat szerinti kereskedelmi üzem kezdete csúszik, akkor még mindig van 1224 hónap arra, hogy a beruházó legalább részben megkezdje a termelést, máskülönben a szerződést felbontják.

Az első tender idején még csak az volt a nem teljesítés szankciója, hogy az adott pályázó 13 hónapig nem vehetett részt tenderen. 2017-ben azonban már szigorodott ez a szabály: a pályázó az adott telephelyre vonatkozóan 24 hónapig nem vehet részt pályázaton. Ez utóbbi már nagyobb visszatartó erővel bír, hiszen kétévente rendeznek tendert.

A brit tenderrendszer komplexitása a kisebb szereplók számára belépési korlátot jelentett, így a nagyobb pályázóknak kedvezett.

A tendereik abból a szempontból alapvetően nem voltak eredményesek, hogy fóként tengeri szélerőmúvi kapacitások szerződtek. Az érettebb (pl. PV) technológiák a 2017es és a 2019-es aukción már nem is indulhattak, ami jelentősen csökkentette a brit megújuló mix diverzitását. Az első fordulóban ráadásul hiba volt az érett technológiák tenderében együtt pályáztatni a szárazföldi szélerőmúvi és a PV-projekteket, mert a britek esetében az utóbbiak drágábbak, így hátrányba kerültek.

Az első és a második tenderen nyertes projektek esetén jelentős késések tapasztalhatóak, és csak elenyésző hányaduk épült meg határidőre. 
Az egyenáras rendszerben (ahol tehát minden pályázó ugyanazt az árat kapja) egyfajta stratégiai licitálás volt megfigyelhető: a befektetők sokszor csak azért ajánlottak alacsonyabb árat, hogy támogatást nyerhessenek el. A 2. ábra bal oldalán látható, hogy az érett technológiák körében (első forduló) az éves átlagos támogatott árak még a legalacsonyabb maximált árat is alig érik el, illetve haladják meg. Az ábra jobb oldalán az éretlenebb technológiák (pl. tengeri szélerőmúvek) éves átlagos támogatott ára látható a kereskedelmi üzembe lépés vállalt éveire vonatkozóan, amelyek már inkább közelítik e technológiák adottságait. Megfigyelhető, hogy a maximált árakat fordulóról fordulóra csökkentették, ezzel próbálták elősegíteni a támogatási költségcsökkenést.

\section{2. ábra ${ }^{8}$}

A brit CfD-tendereken nyertes pályázatok átlagos éves támogatott árai az érett technolóqiák (felső) és a kevésbé érett technolóqiák (alsó) esetében
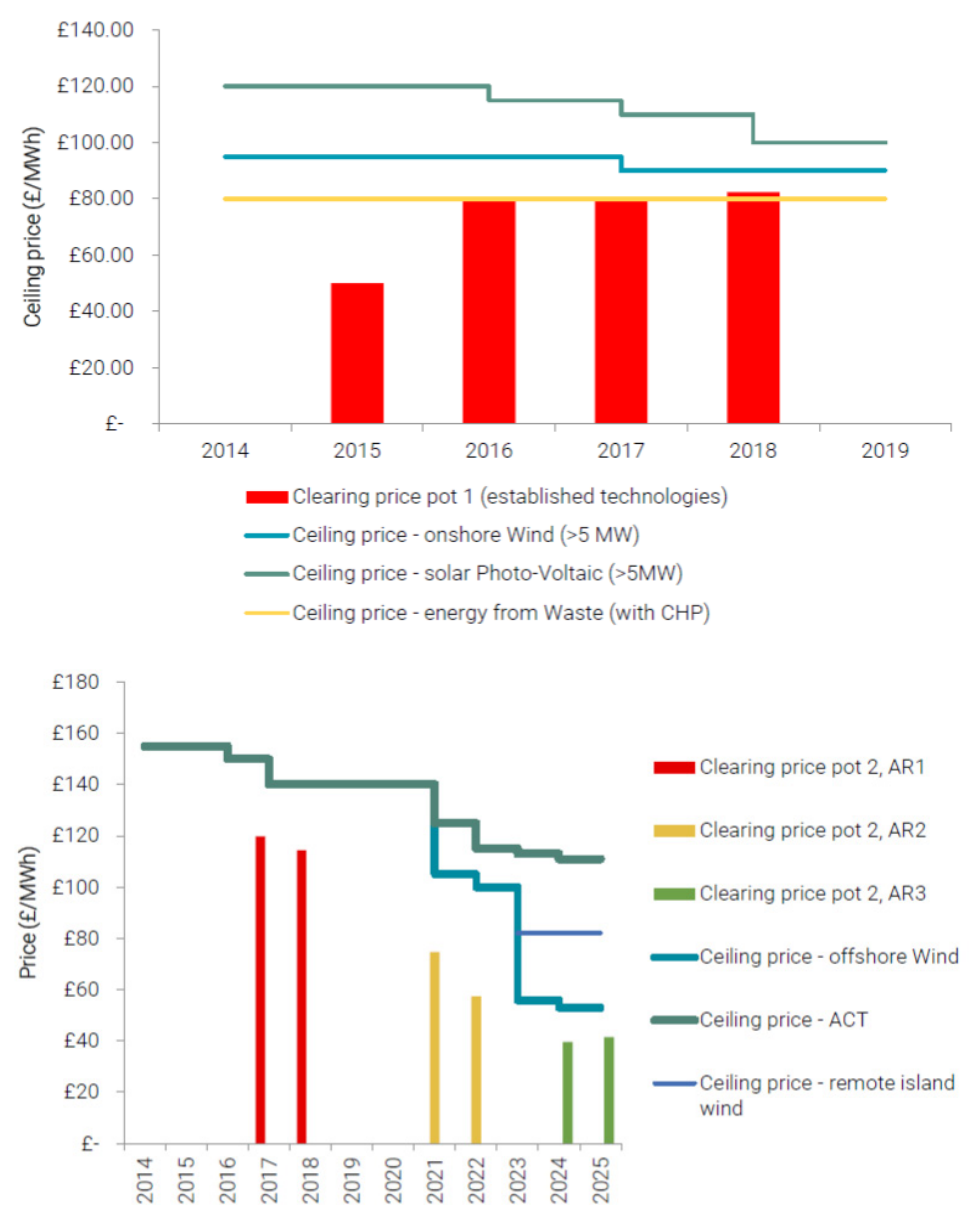

8 Forrás: Woodman és Fitch-Roy, 2019, 27. és 30. o. 


\section{Külügyi Szemle}

Dánia9

A dán tendereken 2004 és 2015 között csak tengeri szélerőmúvi projektek indulhattak, bizonyos előre meghatározott kapacitásra és telephelyre vonatkozóan. Valamennyi nyertes pályamú időre megépült, a leszerződött kapacitásnagysággal.

2016-ban a földre szerelt napelemekre vonatkozóan kölcsönösen nyitott tendereket tartottak a dánok és a németek. A dán tendereken - bár kisebb arányban - német PV-projektek is pályázhattak volna, azonban csak dánok indultak. Összesen kilenc dán PV-projekt nyert a tenderen, amelyek két telephelyhez kapcsolódtak, és 2018-ra meg is épültek.

2018-ban és 2019-ben már több technológiára (szélerőmúvek, illetve PV), valamint több telephelyre vonatkozóan tartottak tendereket, de azokon már fix prémium jellegú támogatásról volt szó, azaz magára a fix prémiumra tettek ajánlatot a pályázók. A változtatás fó indoka, hogy így jobban prognosztizálhatóak a támogatási költségek, hiszen a fix prémium mértéke független a piaci ár alakulásától.10 Ezek a tenderek is egykörös, zárt borítékolású, pay-as-bid aukciók, és 20 évre lehet rajtuk támogatási jogosultságot elnyerni.

A 3. ábrából kitúnik, hogy a technológiasemleges, fix prémiumos tenderek alacsonyabb támogatási költségekhez vezettek, tehát költséghatékony volt a dán rendszer.

3. ábra11

A 2016-ban, 2018-ban és 2019-ben megtartott dán tenderek lebegő, illetve fix prémiumainak súlyozott átlagai (2018. évi árakon)

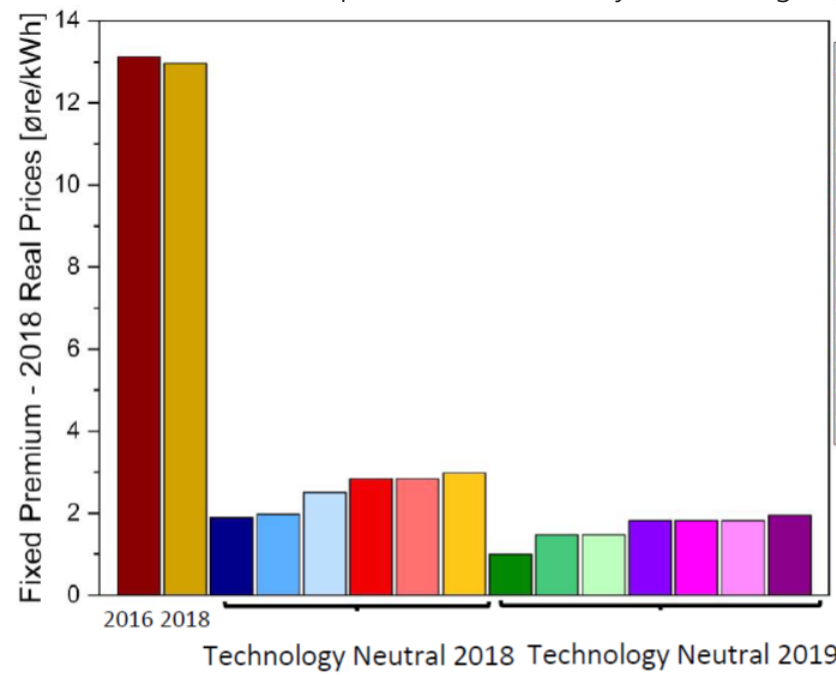

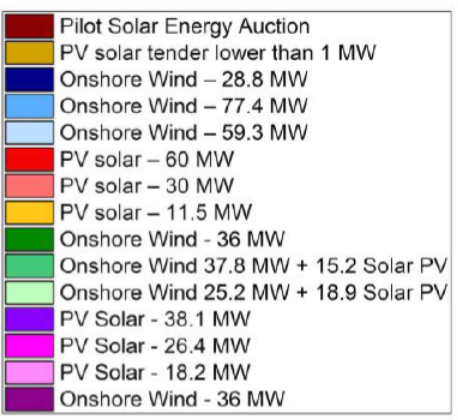

9 Garzón Gonzales és Kitzing, 2019 alapján.

10 A tendereket általában költségvetési korláttal hirdetik meg, és csak addig nyújtanak a legalacsonyabb fix prémiumot ajánló projekteknek támogatást, amíg azt el nem érik.

11 Forrás: Garzón Gonzales és Kitzing, 2019, 29. o. 
Néhány tengeri szélerőművi projekt kivételével mindegyik pályázat időben megvalósult, illetve elkezdték a beruházásokat, tehát ebből a szempontból eredményes volt a dán tenderrendszer. A megvalósítási határidő egyébként általában 2, a tengeri szélerőmúvek esetén azonban 4 év.

A korábbi technológiaspecifikus tengeri szélerőmúvi tendereken - mivel általában egy telephelyre vonatkozóan kértek be ajánlatokat - csak kevés beruházó indult, és nagyon koncentrált volt a nyertes projektek tulajdonosi szerkezete (pl. Vattenfall). A 2018. évi, 1 MW-nál kisebb naperőmúvekre kiírt tenderen is csak a Better Energy projektjei vettek részt - ez szintén nem utal élénk versenyre. A 2018-2019. évi technológiasemleges tendereken is csak két-három beruházó indult. A verseny mértéke tehát alacsony volt Dániában - érdekes módon az árak mégis alacsonyak maradtak.

Kiemelendő, hogy a Better Energy vállalat szinte mindegyik aukción (mind szélerőművi, mind a PV-projektekre vonatkozóan) jelentős kapacitáskiépítésre nyert el jogot. A vállalat úgy nyilatkozott, hogy azért tud a versenytársainál alacsonyabb árakat kínálni, mert teljesen integrált az értéklánca a PV-projektek esetében. Ezáltal alacsonyabbak a fejlesztési, építési és működési költségei, így kevesebb támogatásra van szüksége.

Talán ez az oka, hogy a kevésbé élénk verseny ellenére miért voltak olyan költséghatékonyak a fix prémiumos dán tenderek. Emellett lehetséges, hogy maga a fix prémium is teremt egyfajta beruházói biztonságot, ami csökkenti a kockázati felárakat (azáltal, hogy például olcsóbb hitelekhez tud jutni így a beruházó).

\section{Hollandia'2}

Hollandiában 2011-től a fő megújulóenergia-támogatási program az SDE+ (Stimulering Duurzame Energie), amely a megújulókon alapuló villamosenergia-termelés mellett ilyen hő-, illetve gáztermelést (biogáz) is támogat, akár azok kombinációjaként is. Mindegyik megújuló technológia egyetlen közös költségvetési kereten belül versenyez egymással. A tengeri szélenergia vonatkozásában külön aukciót tartanak, saját költségvetési kerettel. A technológiasemleges, több fordulós, zárt borítékolású aukció a támogatásra fordítható költségvetési keret kimerítéséig tart.

Megjegyzendő, hogy a 2020-ban induló SDE++ tenderrendszer már csak egykörös lesz, továbbá már nem a megújulóalapú termelést, hanem a $\mathrm{CO}_{2}$-kibocsátás csökkentését fogják támogatni, beleértve az ezt célzó ipari technológiákat is.

2016 óta az SDE+ tender minden évben kétkörös (tavaszi és őszi), és mindegyik kör három fordulóból áll, növekvő plafonárakkal (ún. növekvő „clock” aukció). A költségvetési keretet „érkezési sorrend” alapján osztják ki, ami azt jelenti, hogy az aukciókat csak a költségvetési keret tekintetében korlátozzák (nem kapacitás alapján). A keret kimerülésének napján megvizsgálják a beérkezett összes pályázatot, és a benyújtott ajánlati

12 Jakob, Noothout, Blücher és Klessmann, 2019 alapján. 


\section{Külügyi Szemle}

árak alapján rangsorolják azokat. A legkisebb árat ajánlókét fogadják el elsőként. Ha ugyanazon az áron több pályázat is érkezik, akkor sorsolás útján döntik el, hogy melyik projektnek ítélik oda a támogatást.

A tenderen nem lehet magasabb ajánlati árral indulni, mint a technológiaspecifikus, illetve a fordulóspecifikus plafonár. Az előbbit a technológiánkénti maximális licitárnak kell tekinteni, ezzel szemben az utóbbi technológiafüggetlen, ún. szabad kategória (free category).

A holland tenderek ajánlati áras aukciók: a támogatás lebegő prémiumos, de a támogatott árra lehet ajánlatot tenni. Amennyiben a piaci ár 6 egymást követő órán át negatív, nem adnak támogatást.

2012 óta Hollandiában nem pénzügyi jellegú szankciók vannak érvényben, amennyiben a pályázók nem valósítják meg határidőre a nyertes projekteket. Ez azt jelenti, hogy a határidő lejárta után elveszítik a támogatási jogosultságot, és 3 évig nem indulhatnak tenderen. A projektek megvalósítását segíti, hogy azt a holland szabályozó hatóság évente nyomon követi.

A holland tenderrendszer eredményes volt a tekintetben, hogy általában túljelentkezés volt tapasztalható. Megjegyzendő, hogy az első SDE+ tenderek nyertes pályázatainak megvalósítási rátája alacsony volt, de a megvalósítás eredményességérôl csak az öszszes határidő lejárata után vonható le végső konklúzió.

A holland tenderrendszer költséghatékonyságát vizsgálva elmondható, hogy az évek során jelentős volatilitás volt tapasztalható az egyes technológiák, valamint a szabad kategória átlagos ajánlati árai tekintetében (4. ábra). Ennek az a magyarázata, hogy ha egy korai fordulóban egy technológia alacsony árajánlat benyújtásával a rendelkezésre álló pénzügyi kereten belül nagyobb arányt szerez meg, akkor más technológiáknak is alacsony árajánlatot kell tenniük ugyanabban a fordulóban. Ellenkező esetben azt kockáztatják, hogy egyáltalán nem kapnak támogatást (mert kimerül a keret). Ezt az információs problémát úgy oldották meg, hogy 2016-tól megszüntették az eredményeknek a fordulók közötti publikálását. Az áringadozás másik oka a technológiánként meghatározott plafonárakban bekövetkezett változás, főként olyankor, amikor a plafonárhoz közeli ajánlatok érkeztek.

Elmondható, hogy 2017-tól a technológiák átlagában nem csökkentek az ajánlati árak - kivételt a napelemes projektek jelentenek. Tehát a holland tenderek rendszerszinten nem voltak költséghatékonyak (4. ábra). 


\section{4. ábra ${ }^{13}$}

Az átlagos ajánlati árak alakulása és az adott évben leszerződött kapacitásmennyiség a holland SDE+ rendszerben

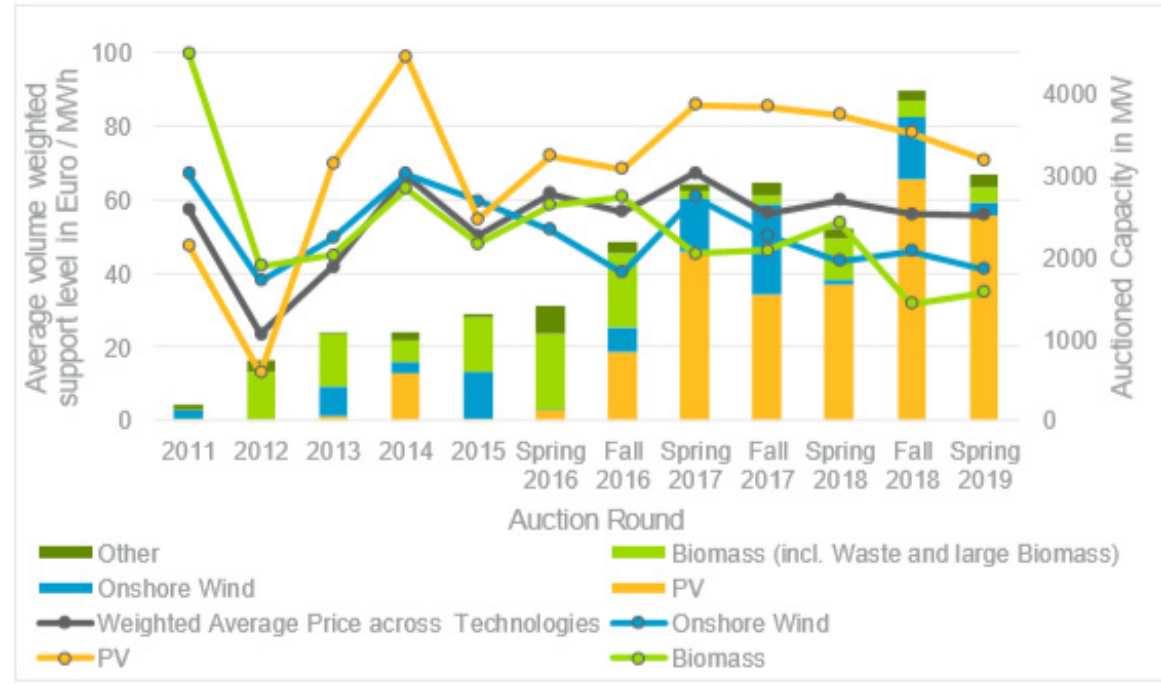

Lengyelország ${ }^{14}$

2016 előtt a megújuló erőmúvek termelését Lengyelországban is zöld bizonyítvány alkalmazásával támogatták, azonban utána - elsősorban a volatilis árak miatt - tenderrendszert vezettek be. A megújuló energiára vonatkozó törvényt azonban azóta többször módosították, ami kiszámíthatatlan beruházási környezetet teremtett.

A lengyel tenderek ajánlati áras aukciók, tehát a nyertes projektek az általuk felajánlott támogatott árat kapják. Az aukciók a szabályozó által kiirt mennyiségen és költségvetési kereten belül zajlanak.

Az aukciós kosarak 3 fő kategóriába sorolhatók:

- technológia,

- méret (1 MW felett, illetve alatt), illetve

- a múködés kezdete szerint (új, illetve régi erőmúvek).

A tendereken való részvétel előfeltétele a bankgarancia formájában benyújtott ajánlati biztosíték, teljesítési garancia viszont nincs. A megújuló technológiák szerint differenciált megvalósítási határidők be nem tartása esetén a pályázó elveszíti a támogatási jogosultságot és az ajánlati biztosítékot, valamint 3 évig nem vehet részt aukciókon (Id. a hollandok esetét, de ott alapvetően nincs ajánlati biztosíték).

13 Forrás: Jakob, Noothout, Blücher és Klessmann, 2019, 16. o.

14 Diallo, Dézsi, Bartek-Lesi, Mezősi, Szajkó, Kácsor és Szabó, 2019 alapján. 


\section{Külügyi Szemle}

2016 és 2018 között három aukciót rendeztek, összesen 18 kosárral, az uniós tagállamokhoz viszonyítva magasnak számító költségvetési kerettel.

Az 1 MW-nál nagyobb kapacitású PV- és szélerőmúvek 2018. évi közös tenderének eredményei érdekes tanulságokkal szolgáltak. A törvényváltozás miatt az volt ugyanis az utolsó év, amikor szárazföldi szélerőmúvek is indulhattak a tenderen, és ez jelentősen befolyásolta annak eredményét. Az új lengyel energiastratégia ugyanis a jövőben inkább a PV-, illetve a tengeri szélerőmúvi projekteket preferálja.

Szinte a teljes kiírt energiamennyiséget sikerült kiosztani, valamint az említett stratégiaváltozás miatt minden nyertes szélenergia-termelő volt. Az aukción megawattóránként 46 eurós ajánlati átlagárat sikerült elérni, amely még a nyugat-európai aukciós eredményekhez viszonyítva is alacsonynak tekinthető. Összehasonlításképpen: a németek által 2018-ban megrendezett két technológiasemleges aukción 53, illetve 56 EUR/MWh átlagár alakult ki.

A lengyelek alacsony átlagos ajánlati ára azonban nem a versenynek köszönhető, hanem a szélerőmúvek stratégiai jellegú alullicitálása okozta (a már említett stratégiai irányváltás miatt a hálózati csatlakozási engedéllyel rendelkező szárazföldi szélerőmúvi projekteknek 2021. július előtt meg kell valósulniuk).

A 2018. évi adatok továbbá azt mutatják, hogy az 1 MW alatti (szárazföldi szél- és PV-) kiserőmúvek kategóriájában kétszer magasabb ajánlati ár alakult ki, mint a nagyobb erőmúvek tenderében (82 EUR/MWh), ami kb. 40 EUR/MWh árkülönbséget jelent (5. ábra). Ennek oka a verseny alacsony szintje (a tervezett mennyiségnek csak a felét osztották ki).

\section{5. ábra ${ }^{15}$}

A legkisebb, a legmagasabb és az átlagos nyertes ajánlati árak alakulása a plafonárakhoz képest, az 1 MW alatti PV- és szárazföldi szélenergia-alapú projektekre vonatkozó lengyel aukciókon, 2016-2018

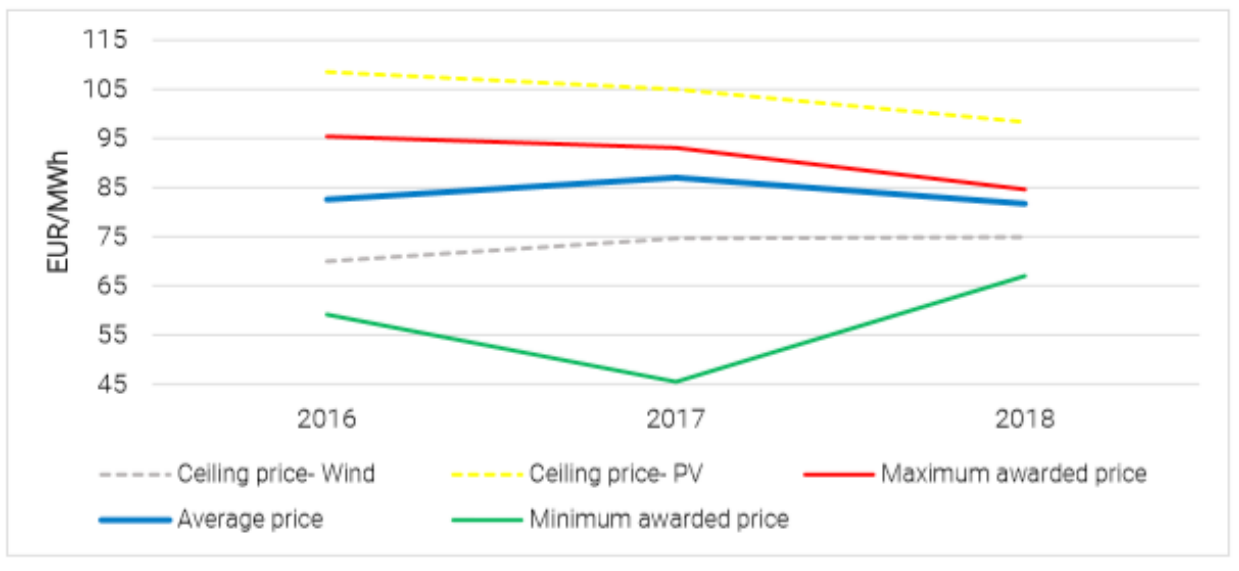

15 Forrás: Diallo et al., 2019, 15. o. 
A görögök elsősorban a gazdasági válság miatt vezették be a tenderrendszert, hogy csökkenteni tudják a megújulóalapú villamosenergia-termelés támogatási költségeit. A másodlagos cél természetesen a megújulók kötelező részarányának elérése 2020ig. Ennek érdekében az illetékes minisztérium meghatározta, hogy addig évente mekkora kapacitást kell kiírni az aukciókon; költségvetési korlát nincs. Évente legalább egy aukciót kell tartani.

A görög tenderrendszer érdekessége, hogy az első körben nem kérnek be ajánlati árakat, csak a projektek nagyságára (kapacitás) vonatkozó ajánlatokat. A második körben már csak az előzetes kvalifikációs kritériumokat teljesítő pályázók adnak be ajánlatokat, 30 perces dinamikus (ún. Yankee) aukció keretében. Ez azt jelenti, hogy egy plafonárról indulnak, és a pályázók onnét csökkenthetik az ajánlati árukat a megadott időintervallumon belül. Ezek után ár szerint rendezik sorba az ajánlatokat, és mindenki a saját ajánlati árát kapja (statikus pay-as-bid). Végül a nyertes pályázókkal szerződést kötnek, amely szerint 20 évig részesülhetnek lebegő prémium jellegú támogatásban. ${ }^{17}$

2016-ban volt egy pilot PV-aukció, de a tenderrendszert csak 2018-ban vezették be. A görög tenderek általában technológiaspecifikusak, de 2019 áprilisában meghirdettek egy pilot közös PV-szél-tendert is.

Görögországban a PV- és a szárazföldi szélerőmúvek kapcsán csak tenderen nyerhető el támogatás. Minden egyéb megújuló technológiára vonatkozóan kötelező átvételi, illetve tender nélküli, prémium jellegű támogatás igényelhető, mivel a görög szabályozó hatóság szerint azok esetében a verseny nem biztosított.

Ajánlati és teljesítési biztosíték befizetése révén szúrik ki a komolytalan ajánlatokat. További kvalifikációs követelmény a termelési engedély (kivéve kis projektek), illetve a hálózati csatlakozási szerződés megléte. Megjegyzendő, hogy a jövőben részvételi díj befizetése is kötelező lesz.

A megvalósítási határidők technológiánként és méretenként különböznek. Nem teljesítés esetén a támogatási szerződés felmondható, az ajánlati és a teljesítési biztosíték visszatartható (egy megújuló projekteket támogató számlára kerül), valamint végső esetben a termelési engedélyt és/vagy a hálózati hozzáférési jogot is visszavonhatják.

A görög tenderek eredményesen csökkentették a támogatási költségeket (az átlagos ajánlati árakat), ezért a már említett cél megvalósult. Néhány kivételtől eltekintve az is elmondható, hogy gyakori volt a túljelentkezés (6. ábra).

16 Anatolitis, 2020 alapján.

17 Megjegyzés: amennyiben két egymást követő órán át negatív a piaci ár, nem fizetnek prémiumot, és ha a megtermelt villamos energia piaci értéke meghaladná a tenderen elnyert ajánlati árat, a különbséget a termelőnek vissza kell fizetnie (az összeg egy külön RESszámlára kerül). Ezt láthattuk a brit és a holland tenderrendszerben is. 


\section{Külügyi Szemle}

\section{6. ábra ${ }^{18}$}

A görög tendereken kiírt pályázó és nyertes kapacitásmennyiségek, plafonárak és átlagos ajánlati árak alakulása

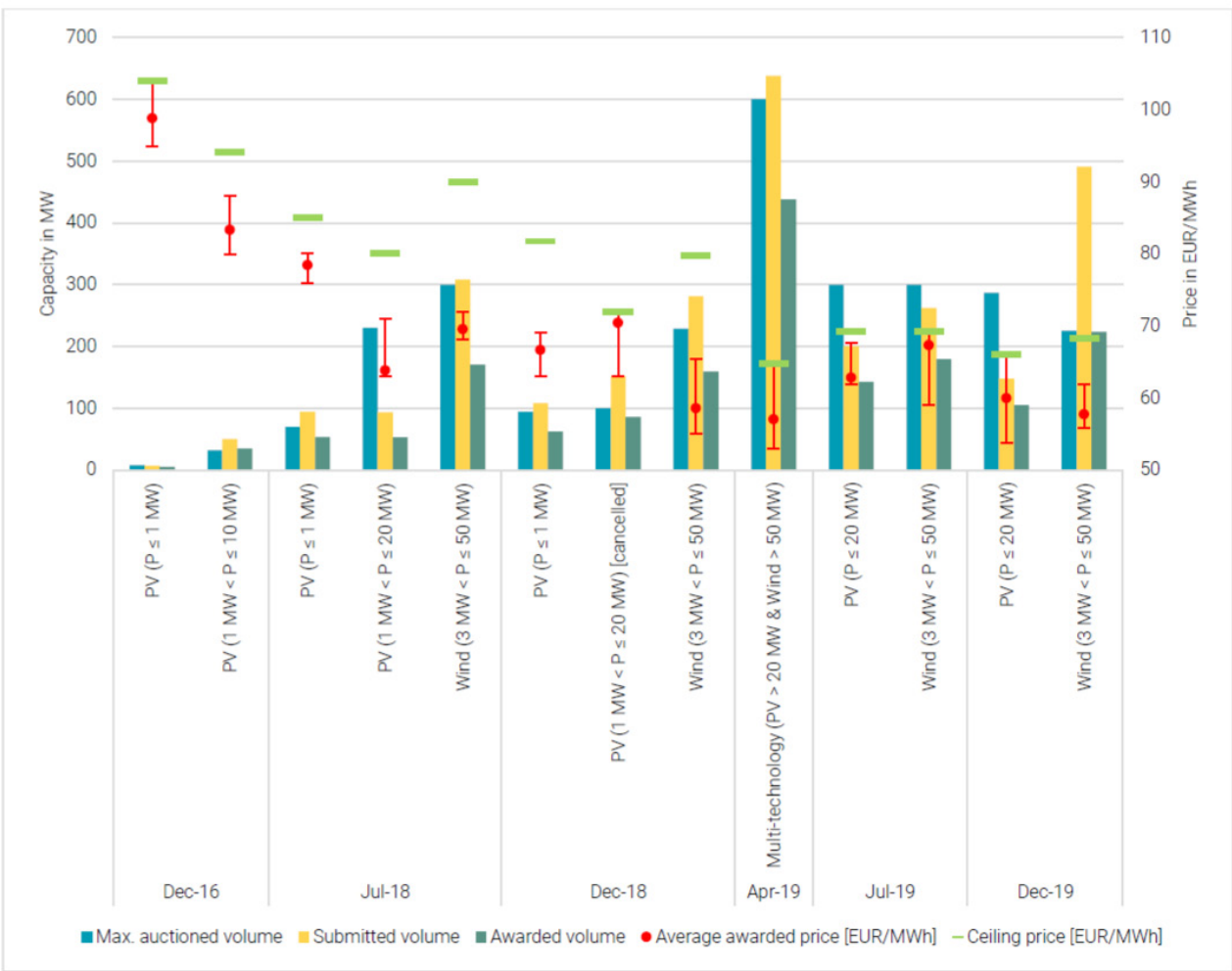

Megjegyzendő, hogy a 2018. júliusi tender 1. kategóriájában 100 százalékos megvalósítási arányról beszélhetünk, tehát az eredményesnek tekinthető volt. Ennek hátterében az állhat, hogy félévente jelenteni kell a szabályozó hatóságnak a projekt előrehaladását, ami ösztönözte a megvalósítást. A termelési engedélynek az előzetes kvalifikációs kritériumként történő alkalmazása azonban nem szerencsés, mert a kiadása gyakran elhúzódik Görögországban, ami csökkenti a tenderen részt vevő projektek számát. Ez jól mutatja, hogy a tender megfelelő designja mellett fontos lehet az engedélyezési folyamatok egyszerúsítése is annak érdekében, hogy a tenderrendszer sikeres legyen.

18 Forrás: Anatolitis, 2020, 13. o. 


\section{A hazai METÁR tenderrendszer múködésének rövid bemutatása, az első tapasztalatok}

Hazánkban - az uniós elvárásoknak megfelelően - 2017-ben vezették be az új megújuló támogatási rendszert (METÁR), ${ }_{1}^{19}$ amely a fix kötelező átvételi tarifa helyett bizonyos mérethatár felett lebegő prémium jellegú támogatást nyújt. Ez azt jelenti, hogy a termelő a piacon értékesíti a megújuló energiaforrás révén megtermelt villamos energiát, majd a piaci ár nagyságától függő lebegő prémiumot (ún. zöld prémium) kap (zöld prémium: a támogatott ár és a referencia piaci ár különbsége).

2019. április végéig az 1 MW kapacitás alatti új belépő megújuló termelők (kivéve szélerőmúvek) pályázat nélkül igényelhettek zöld prémium jellegú támogatást, de azóta már csak pályázat útján (METÁR-tender) ${ }^{20}$ lehet azt elnyerni.

A METÁR-tendereket az energiapolitikáért felelős miniszter felkérésére a Magyar Energetikai és Közmú-szabályozási Hivatal (MEKH) írja ki és bonyolítja le. Az első METÁR-tendert 2019. szeptember 2-án írta ki az MEKH, november 4. és december 2. között lehetett a pályázatokat beadni. Az eredmények 2020. március 27. óta érhetőek el a MEKH honlapján. ${ }^{21}$

A METÁR-tenderek technológiasemleges, egykörös, ajánlati áras aukciók. A feltételeknek megfelelő pályázatok között csak az induló támogatott árra tett ajánlat nagysága dönt. Azonos ár esetén további szempontokat is figyelembe lehet venni. A maximális támogatási időtartam az NFMR szerint 20 év, a nyertes ajánlatokban szereplő induló támogatott ár mellett (az első METÁR-tenderen 15 évre nyerhető el támogatás). A maximált árat (a benyújtható legmagasabb ajánlati árat) a kormányrendelet (Wolters Kluwer, 2017) határozza meg (1. melléklet 3.b pont tárgyévre indexált értéke, ami a 2019. évi tenderen 26,08 Ft/kWh volt).

Az NFMR 1. melléklete szerint 2016-2019 között évente 1 milliárd Ft támogatás volt kiosztható pályázat útján, ez az összeg az idei évtől 2026-ig évente 2,5 milliárd Ft lesz. Az egy adott évben ki nem osztott támogatás a következő évi keretet növeli. Az első METÁR-tenderen 1 milliárd forint, illetve évi 200 gigawattóra (GWh) a támogatási keret. A mennyiségi korlát bevezetésére azért volt szükség, mert ha a támogatott ár a referencia piaci árhoz nagyon közel van, akkor a költségvetési nem, csak a mennyiségi korlát hatásos.

Kétféle támogatási kategóriát alakítottak ki, amelyeken belül a támogatási korlátokat a 7. ábra szemlélteti.

19 Bővebben: Wolters Kluwer, 2017.

20 A rendeleti feltételekhez Id. a 62/2016. (XII. 28.) NFM rendeletet (a továbbiakban: NFMR): Wolters Kluwer, 2016.

21 Magyar Energetikai és Közmű-szabályozási Hivatal, 2020b; Magyar Energetikai és Közműszabályozási Hivatal, 2020a. 


\section{Külügyi Szemle}

\section{7. ábra 22}

Az első METÁR-tender támogatási kategóriái és a támogatási korlátok

\section{0,3 MW feletti, de $1 \mathrm{MW}$ alatti \\ teljesítményű erőmüegységek \\ támogatási kategóriájában \\ összesen}

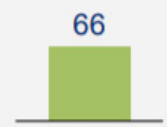

GWh/év
333

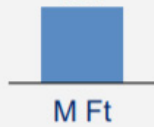

Legalább 1 MW, de legfeljebb

20 MW teljesítményü erőmüegységek támogatási kategóriájában összesen

134

667

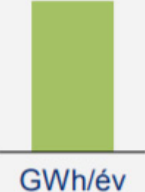

A pályázatokat az ajánlati ár szerint növekvő sorba rendezi a MEKH. Azok a legalacsonyabb ajánlati árú pályázatok minősülnek nyertesnek, amelyekre sem a kumulált igényelt támogatott mennyiség (GWh/év), sem a kumulált éves új támogatás (millió Ft) nem éri el a korlátot.

A pályázaton való részvétel feltétele az ajánlati biztosíték banki letétbe helyezése. Amennyiben a pályázó nyer, de azt követően nem igazolja az előírtaknak megfelelően az ajánlati biztosítékot, úgy elveszti a támogatási jogosultságát és az ajánlati biztosítékot. Pályázata elutasítása vagy visszavonása esetén az ajánlati biztosítékot visszakapja.

A teljesítési biztosítékot a nyertesnek a határozat kézhezvételét követően kell letétbe helyeznie, és az akkor szabadul fel, ha a pályázó 3 éven belül megkezdi a kereskedelmi üzemet. Ha ez nem történik meg, a teljesítési biztosítékot elveszíti, de még marad egy éve a kereskedelmi üzem megkezdésére.

Az első METÁR-tenderre összesen 168 pályázat érkezett, 348,97 MW összesített névleges teljesítőképességgel. Ebből 49 pályázat volt érvénytelen (79,54 MW) - ez magas szám, és 29 százalékos arányt jelent. Azaz a pályázatok 71 százaléka, 119 darab (269,43 MW) volt érvényes; közülük 72-t (131,83 MW), azaz 60,5 százalékukat nyilvánították nyertesnek (1. táblázat).

Az első METÁR-tendert technológiasemlegesként hirdették meg ugyan (a szélerőmúvek kivételével ${ }^{23}$ gyakorlatilag minden megújuló technológia indulhatott), az mégis inkább a naperőmúveknek kedvezett: egyetlen depóniagázos erőmú kivételével a pályázók mind naperőmüvek voltak.

A 119 érvényes pályázatból 45 a "nagy" (1-20 MW), 74 pedig a "kicsi" (0,3-1 MW) kategóriába került. Az utóbbiban 61 (82\%), míg az előbbiben csak 11 nyertest (24\%) hirdettek.

22 Forrás: Magyar Energetikai és Közmú-szabályozási Hivatal, 2020c.

23 A szélerőmúvek esetében előzőleg külön tendert kell kiírni a létesítési jog elnyerésére, és engedélyezési akadályai is vannak. 
Az 1-20 MW-os kategóriában jelentős volt a túljelentkezés: az érvényesen igényelt volumen (összesen 323,12 GWh) közel a 2,5-szerese volt a kiosztható 134 GWh-s keretnek. Ezzel szemben a 0,3-1 MW igénylése terén csak enyhe, 18 százalékos túljelentkezés volt tapasztalható (77,64 GWh érvényesen igényelt összvolumen a kiosztható 66 GWh-val szemben).

A két kategóriára benyújtott pályázatok együttes aránya azonban kétszeres (túljelentkezés), ennek alapján eredményesnek mondható a tender. (A megvalósítási arány természetesen most még nem elemezhető ki, az legkorábban 2-3 év múlva lesz lehetséges.)

A két kategória eredményét az 1. táblázat foglalja össze. Az értékek megfelelnek az előzetes várakozásoknak, hiszen a magas piaci árak miatt alacsony a várható támogatástartalom, így inkább a mennyiségi korlát releváns (évi 200 gigawattóra az 1 milliárd forinttal szemben).

\section{1. táblázat ${ }^{24}$}

A "kicsi" és a "nagy" kategória nyerteseinek támogatása (millió forint/év) és támogatott mennyisége (GWh/év), valamint a kiosztási arányok az első METÁR-tenderen

\begin{tabular}{|l|c|c|c|c|}
\hline & $\begin{array}{c}\text { Kiosztott } \\
\text { éves új } \\
\text { támogatás } \\
\text { (millió forint) }\end{array}$ & $\begin{array}{c}\text { Kiosztott éves } \\
\text { új támogatás a } \\
\text { kiosztható támogatás } \\
\text { százalékában }\end{array}$ & $\begin{array}{c}\text { Kiosztott } \\
\text { támogatott } \\
\text { mennyiség } \\
\text { (GWh/év) }\end{array}$ & $\begin{array}{c}\text { Kiosztott támogatott } \\
\text { mennyiség a } \\
\text { kiosztható mennyiség } \\
\text { százalékában }\end{array}$ \\
\hline Kicsi kategória & 207,7 & $62,4 \%$ & 65,6 & $99,4 \%$ \\
\hline Nagy kategória & 21,4 & $3,2 \%$ & 127,4 & $95,1 \%$ \\
\hline Összesen & $\mathbf{2 2 9 , 0}$ & $\mathbf{2 2 , 9 \%}$ & $\mathbf{1 9 3 , 0}$ & $\mathbf{9 6 , 5 \%}$ \\
\hline
\end{tabular}

Az ajánlati árak kategóriánkénti alakulását a 2. táblázat szemlélteti. A kicsi kategóriában 24,81 Ft/kWh volt az elnyert támogatott mennyiséggel (MWh) súlyozott átlagos nyertes ajánlati ár, míg ugyanez a nagy kategóriában - feltehetően méretgazdaságossági előnyök miatt - némileg alacsonyabb, 21,69Ft/kWh volt.

\section{2. táblázat ${ }^{25}$}

A kis és nagy kategória ajánlati árai az első METÁR-tenderen

\begin{tabular}{|l|c|c|c|}
\hline & $\begin{array}{c}\text { Legalacsonyabb } \\
\text { nyertes ajánlati ár } \\
(\mathrm{Ft} / \mathrm{kWh})\end{array}$ & $\begin{array}{c}\text { Legmagasabb } \\
\text { nyertes ajánlati ár } \\
(\mathrm{Ft} / \mathrm{kWh})\end{array}$ & $\begin{array}{c}\text { Elnyert MWh-val súlyozott } \\
\text { átlagos nyertes ajánlati ár } \\
\text { (Ft/kWh) }\end{array}$ \\
\hline Kicsi kategória & 21,20 & 25,94 & 24,81 \\
\hline Nagy kategória & 20,20 & 22,75 & 21,69 \\
\hline
\end{tabular}

24 Forrás: Magyar Energetikai és Közmú-szabályozási Hivatal, 2020c, 6. o.

25 Forrás: Magyar Energetikai és Közmú-szabályozási Hivatal, 2020c, 8. o. 


\section{Külügyi Szemle}

Amennyiben a korábbi átlagos KÁT-árakhoz (kötelező átvételi tarifa) viszonyítjuk ezeket az átlagos nyertes ajánlati árakat, arra az eredményre jutunk, hogy a tendereken sokkal alacsonyabb támogatott árak alakultak ki a két támogatási kategóriában, mint a 2020. évi átlagos KÁT-árak a nap-, illetve depóniagáz-erőművekre vonatkozóan (8. ábra). Az első METÁR-tender tehát ebből a szempontból nézve költséghatékony eredményre vezetett.

8. ábra ${ }^{26}$

Az átlagos KÁT-árak alakulásának és az első METÁR-tenderen nyertes ajánlatok átlagárainak az összehasonlítása

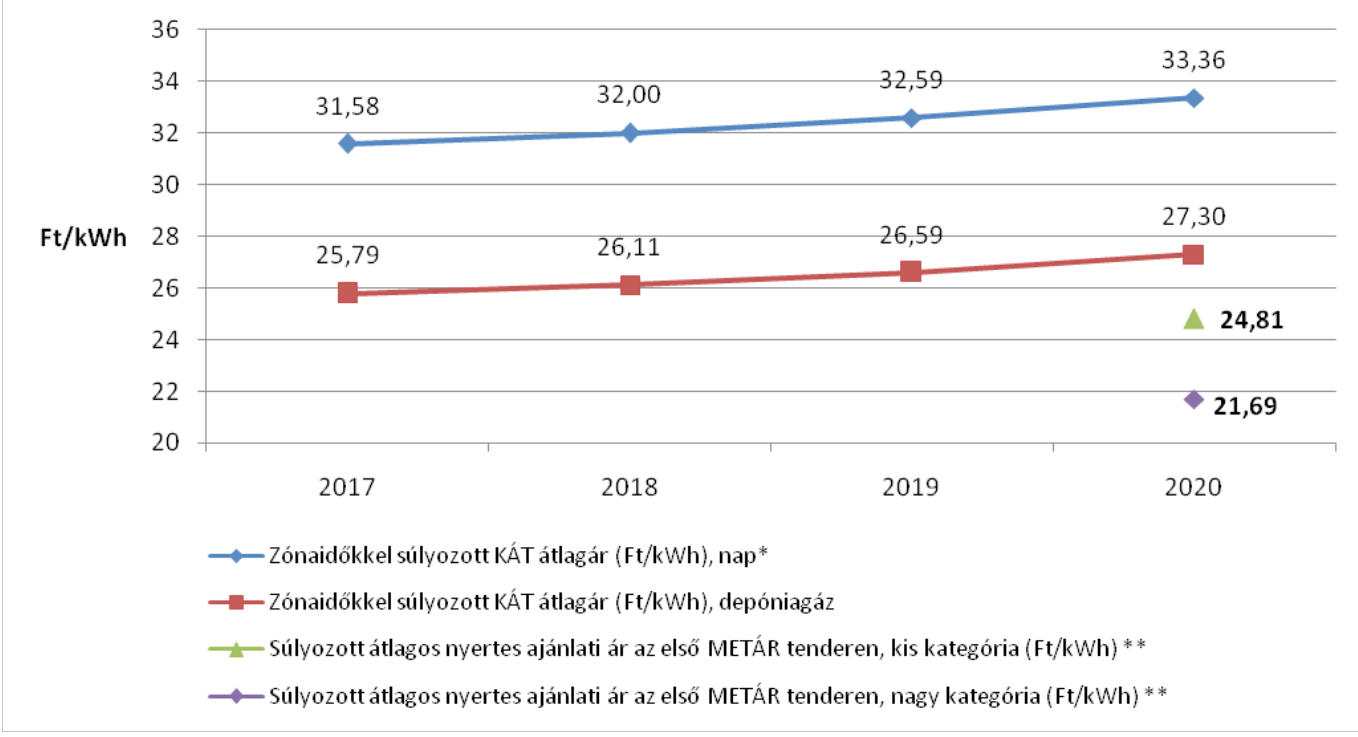

Megjegyzés:

* A KÁT-határozatot 2008-tól adták ki, és 20 MW vagy annál kisebb naperőműre vonatkozik. ** A nyertes ajánlati árak az elnyert támogatási mennyiséggel súlyozottan.

\section{Mit tanulhatunk az európai megújuló tenderekböl? Külföldi best practice megoldások a hazai METÁR-tenderrendszer esetleges továbbfejlesztése kapcsán}

A vizsgált európai megújuló tenderrendszerek (Dánia, az Egyesült Királyság, Görögország, Hollandia, Lengyelország és Németország) elemzése kapcsán számos olyan, ún. best practice (bevált gyakorlat) azonosítható, amely a hazai METÁR-tenderek esetleges továbbfejlesztésekor követendő példaként szolgálhat.

26 Forrás: Magyar Energetikai és Közmű-szabályozási Hivatal, 2019; Magyar Energetikai és Közmú-szabályozási Hivatal, 2020c, saját szerkesztés. 
A német példa alapján az innovációs, ún. kísérleti jellegű tenderek tartása érdekes módja lehet hazánkban is az egyes tender designelemek pilot jellegú bevezetésének. A németeknél a tervezett innovációs tenderek célja, hogy kipróbálják a fix prémiumra való áttérést, mivel az kisebb piaci kockázattal jár (hiszen a támogatás tartalma nem függ a piaci ár alakulásától).

Megjegyzendő, hogy a dán megújuló tenderek esetében, ahol 2018 óta már fix prémiumra lehet pályázni, a gyakorlatban is megfigyelhetô volt a fenti hatás, hiszen az addigi legalacsonyabb fix prémiumokra érkeztek ajánlatok - feltehetően amiatt is, hogy a befektetők kisebb kockázati felárral számoltak a fix támogatástartalom miatt.

Hazánkban a későbbiek során releváns kérdéssé válhat a hálózati szúk keresztmetszetek problémája, mivel a Nemzeti Energia- és Klímaterv (NEKT) alapján mintegy 6500 MW-nyi napelemes kapacitás épülne be 2030-ig. Németországban a PV- és a széltendereken ezt a problémát úgy próbálták orvosolni, hogy mindkét technológiára vonatkozóan egy ún. elosztó hálózati komponenst (Verteilernetzkomponente) vezettek be, amely egyfajta bonus-malus rendszerként múködik: a leterhelt elosztóhálózati területeket alulkompenzálja, a nem leterhelteket felül.

A németeknél bevált gyakorlattá vált, hogy egy előre meghatározott ütemterv (ún. tendernaptár) alapján inkább évente többször írnak ki kisebb kapacitásmennyiségekre tendereket, ami egyfelől nagyobb kiszámíthatóságot jelent a megújuló befektetők számára, másfelől folyamatos és kiszámítható megújulókapacitás-bővüléshez vezet. Hazánkban is megfontolandó lenne, hogy az illetékes minisztérium (Innovációs és Technológiai Minisztérium, ITM) az ad hoc jellegú kiírások helyett egy tendernaptár alapján (pl. tavasszal és ősszel) kérje fel az MEKH-t a tenderek kiírására.

A német tendereken támogatást elnyert projektek eddig kiemelkedően magas, 90100 százalékos arányban valósultak meg. A beruházók szerint ez a megfelelő előminősítési kritériumok, valamint a hatékony szankcionálási eszközök (pl. ajánlati, teljesítési biztosítékok, pénzügyi szankciók) mellett a támogatási jogosultság átruházhatóságának, valamint a telephely-módosítások lehetőségének is köszönhető. Hazánkban a nyertes pályázó az általa beadott ajánlati ár 1 Ft/kWh-val történő csökkentése ellenében módosíthatja fizikailag a telephelyet. A METÁR-tenderen elnyert támogatási jogosultságot azonban önmagában nem lehet eladni vagy átruházni (csak a tulajdonosi szerkezet változása, illetve a jogutódlás megengedett). Kérdés, hogy a támogatási jogosultság átruházásának engedélyezése nálunk is növelné-e a nyertes projektek megvalósítási arányát. Erre a pályáztatás kezdeti szakaszában még nem lehet érdemben választ adni. Amennyiben két-három év múlva úgy túnik, hogy a projektek megvalósítása nem halad előre a kívánt mértékben, úgy vizsgálandó lesz annak az oka, és a lehetséges megoldási alternatívák keresése válik szükségessé.

A brit megújuló tenderrendszer sem a nagyobb pályázóknak kedvező komplexitása okán, sem az egyenáras rendszerben rejlő stratégiai licitálás veszélye miatt nem hozható fel pozitív példaként hazánk számára. 


\section{Külügyi Szemle}

A dán fix prémiumos tenderrendszer költséghatékony ugyan (ez többek között annak tudható be, hogy a fix prémium kedvezőbb a befektetők számára), azonban mégsem javasoljuk annak a METÁR keretében történő bevezetését. A lebegő prémium ugyanis támogatásként jobban tudja tükrözni a piaci árak változását (például magas piaci árak mellett nem kompenzálja felül a termelőt), és a nemzetközi gyakorlat alapján is inkább ez a prémiumtípus a jellemzőbb.

A vizsgált európai megújuló tenderrendszerek kapcsán megállapítható, hogy a nyertes projektek megvalósítását általában nem követi nyomon a tendert kiíró hatóság, így hazánkban sem. Jó példaként említhető azonban e tekintetben Hollandia, illetve Görögország, ahol az illetékesek rendszeresen ellenőrzik a megvalósítást (a hollandok esetében évente, a görögöknél félévente szükséges jelentést tennie a beruházónak a projekt előrehaladottsági állapotáról). A gyakorlati tapasztalatok szerint ez a kötelezettség növelte a nyertes projektek megvalósulási arányát. Ily módon javasolható, hogy hazánkban is múködjön egy hasonló monitoring rendszer (amelynek felelőse értelemszerúen a kíró hatóság, azaz az MEKH lehetne).

A holland megújuló tenderrendszer egyelőre szintén nem követendő példa hazánk számára, mivel ott az egyes fordulók között információs probléma merült fel: eleinte minden forduló után publikálták az eredményeket, így a pályázók a többieké ismeretében stratégiai jelleggel alacsonyabb vagy magasabb ajánlatot tudtak tenni a következő körben (ezt később úgy oldották meg, hogy a fordulóközi eredményeket már nem tették közzé). Többek között ez az információs probléma vezetett a holland tenderek meglehetôsen volatilis áraihoz is. Úgy gondoljuk, hogy Magyarországon - fóként a megújuló tendereztetés kezdeti szakaszában - továbbra is az egyszerúbb, egykörös tenderrendszerek fenntartása lehet célszerú. A hollandok éves, utólagos monitoringrendszere azonban példaértékú lehet a hazai tenderrendszer esetleges jövőbeli továbbfejlesztésekor.

A lengyel tenderrendszerben szintén voltak olyan elemek (pl. jogszabályváltozásról annak megjelenése előtt szerzett ismeretek miatti stratégiai alullicitálás vagy a jogszabályi környezet gyakori változása miatt kialakuló befektetői bizonytalanság), amelyek nem követendőek hazánk számára.

Érdekes és talán hazánkban is alkalmazható eleme a görög megújuló tenderrendszernek, hogy csak a napelemes technológiák, valamint a szárazföldi szélerőmúvek esetében kell tenderen indulni a támogatás elnyerése érdekében, míg az egyéb megújuló technológiák esetén kötelező átvételi, illetve tender nélküli prémium igényelhető. A görögök ez utóbbit azzal indokolják, hogy e technológiák kapcsán nem biztosított a verseny megfelelő mértéke. Esetleg érdemes volna a hazai tenderrendszer továbbfejlesztése előtt lefolytatni egy olyan jellegú vizsgálatot, amely alapján megállapítható lenne, hogy mely megújuló technológiák esetében biztosítható a megfelelő mértékú verseny. 
A görögöknél a visszatartott ajánlati és teljesítési biztosíték egy megújuló projekteket támogató számlára kerül. Véleményünk szerint ennek az intézkedésnek a hazai bevezetése is megfontolandó lehet a tenderrendszer továbbfejlesztésekor. Emellett vizsgálandó a már említett féléves (vagy akár éves) szintű utólagos monitoringrendszer bevezetése (főként abban az esetben, ha a nyertes projektek megvalósulása az elkövetkező két-három évben az elvárt szinttől elmaradna).

\section{Irodalomjegyzék}

Anatolitis, Vasilios (2020). Auctions for the Support of Renewable Energy in Greece. Aures II. A letöltés ideje: 2020. május 19. http://aures2project.eu/wp-content/ uploads/2020/03/AURES_II_case_study_Greece.pdf.

AURES II (2020). Az AURES II projekt weboldala. A letöltés ideje: 2020. július 20. http:// aures2project.eu/.

buzer.de (2020). Erneuerbare-Energien-Gesetz (EEG, 2017). A letöltés ideje: 2020. augusztus 8. https://www.buzer.de/Anlage_2_EEG.htm.

CEER (2018). Tendering Procedures for RES in Europe: State of Play and First Lessons Learnt. A letöltés ideje: 2020. július 20. https://www.ceer.eu/documents/104400/-/L167af87c-5472-230b-4a19-f68042d58ea8.

Diallo, Alfa, Dézsi Bettina, Bartek-Lesi Mária, Mezősi András, Szajkó Gabriella, Kácsor Enikő és Szabó László (2019). Auctions for the Support of Renewable Energy in Poland. Aures II. A letöltés ideje: 2020. május 19. http://aures2project.eu/wp-content/ uploads/2019/08/Polish-Auctions_final.pdf.

EBRD (2018). Competitive Selection and Support for Renewable Energy Policy. Guidelines Prepared jointly by the European Bank for Reconstruction and Development and the Energy Community Secretariat in Collaboration with the International Renewable Energy Agency. March 2018. A letöltés ideje: 2020. július 20. https://www.ebrd.com/ cs/Satellite?c=Content \&cid=1395272817389\&d=\&pagename=EBRD\%2FContent $\% 2 F$ DownloadDocument.

Garzón Gonzales, Mario és Kitzing, Lena (2019). Auctions for the Support of Renewable Energy in Denmark. Aures II. A letöltés ideje: 2020. május 19. http://aures2project.eu/ wp-content/uploads/2019/12/AURES_II_case_study_Denmark.pdf.

Haufe, Marie-Christin és Ehrhart, Karl-Martin (2018). Auctions for Renewable Energy Support - Suitability, Design, and First Lessons Learned. Energy Policy, 121, 217-224. A letöltés ideje: 2020. július 20. https://www.sciencedirect.com/science/article/abs/ pii/S0301421518304166.

IRENA (2015). Renewable Energy Auctions: A Guide to Design. A letöltés ideje: 2020. július 20. https://www.irena.org/publications/2015/Jun/Renewable-Energy-AuctionsA-Guide-to-Design.

IRENA (2019). Renewable Energy Auctions: Status and Trends Beyond Price. A letöltés ideje: 2020. július 20. https://www.irena.org/publications/2019/Dec/Renewableenergy-auctions-Status-and-trends-beyond-price.

Jakob, Martin, Noothout, Paul, von Blücher, Felix és Klessmann, Corinna (2019). Auctions for the Support of Renewable Energy in the Netherlands. Aures II. A letöltés ideje: 


\section{Külügyi Szemle}

2020. május 19. http://aures2project.eu/wp-content/uploads/2019/12/AURES_II_ case_study_Netherlands.pdf.

Magyar Energetikai és Közmú-szabályozási Hivatal (2019). A KR. szerinti kötelező átvételú villamos energia átvételi árai (áfa nélkül) a megújuló energiaforrásból, illetve hulladékból nyert energiával termelt villamos energiára vonatkozóan (HUF/ kWh). A letöltés ideje: 2020. május 19. http://www.mekh.hu/download/a/52/c0000/ kat_arak_megujulo_hulladek_2008_2020.xlsx.

Magyar Energetikai és Közmú-szabályozási Hivatal (2020a). A 2019-es METÁR pályázat eredményhirdetése. A letöltés ideje: 2020. október 2. http://www.mekh.hu/a-2019es-metar-palyazat-eredmenyhirdetese.

Magyar Energetikai és Közmú-szabályozási Hivatal (2020b). METÁR-tender. A letöltés ideje: 2020. október 2. http://www.mekh.hu/metar-tender.

Magyar Energetikai és Közmú-szabályozási Hivatal (2020c). Az Értékelő Bizottság öszszefoglaló értékelése a 2019. szeptember 2-án kiiŕt METÁR pályázatról. A letöltés ideje: 2020. október 2. http://www.mekh.hu/download/8/69/c0000/osszefoglalo_ ertekeles.pdf.

Magyar Energetikai és Közmú-szabályozási Hivatal (2020d). Az Értékelő Bizottság öszszefoglaló értékelése a 2019. szeptember 2-án kiírt METÁR pályázatról. Mellékletek. A letöltés ideje: 2020. május 19. http://www.mekh.hu/download/9/69/c0000/ osszefoglalo_ertekeles_mellekletek.xlsx.

Matthäus, David (2020). Designing Effective Auctions for Renewable Energy Support. Energy Policy, 142. A letöltés ideje: 2020. július 20. https://www.sciencedirect.com/ science/article/abs/pii/S0301421520302135.

Mora, David, Kitzing, Lena, Rosenlund Soysal, Emilie, Steinhilber, Simone, Del Río, Pablo, Wigand, Fabian, Klessmann, Corinna, Tiedermann, Silvana, Amazo, Ana, Welisch, Marijke, Kreiß, Jan, Fitch Roy, Oscar és Woodman, Bridget (2017). Auctions for Renewable Energy Support - Taming the Beast of Competitive Bidding. Final Report of the AURES Project. Auresproject.eu. A letöltés ideje: 2020. július 20. https:// auresproject.eu/sites/auresproject.eu/files/media/documents/aures-finalreport.pdf.

Sach, Thobias, Lotz, Bastian és von Blücher, Felix (2019). Auctions for the Support of Renewable Energy in Germany. AURES II. A letöltés ideje: 2020. május 19. http:// aures2project.eu/wp-content/uploads/2020/04/AURES_II_case_study_Germany_ v3.pdf.

Wolters Kluwer (2016). 62/2016. (XII. 28.) NFM rendelet a megújuló energiaforrásból származó villamos energia termelési támogatás korlátairól és a prémium típusú támogatásra irányuló pályázati eljárásról. A letöltés ideje: 2020. július 20. https://net. jogtar.hu/jogszabaly?docid=a1600062.nfm.

Wolters Kluwer (2017). 299/2017. (X. 17.) Korm. rendelet a megújuló energiaforrásból termelt villamos energia kötelező átvételi és prémium típusú támogatásáról. A letöltés ideje: 2020. július 20. https://net.jogtar.hu/jogszabaly?docid=A1700299.KOR.

Woodman, Bridget és Fitch-Roy, Oscar (2019). Auctions for the Support of Renewable Energy in the UK. AURES II. A letöltés ideje: 2020. május 19. http://aures2project.eu/ wp-content/uploads/2019/10/AURES_II_UK_case_study.pdf. 